\title{
Heparin and Heparan Sulfate Partially Inhibit Induction of Acetylcholine Receptor Accumulation by Nerve in Xenopus Culture
}

\author{
Yukiko Hirano and Yoshiaki Kidokoro \\ Jerry Lewis Neuromuscular Research Center, UCLA School of Medicine, Los Angeles, California 90024
}

\begin{abstract}
It has been demonstrated that ACh receptors in Xenopus nerve-muscle cultures migrate in the membrane to the nerve contact area during junction formation (Anderson et al., 1977) and that "diffusion trapping" is the major mechanism for nerve-induced receptor accumulation (Kidokoro and Brass, 1985; Kuromi et al., 1985; Kidokoro et al., 1986). A crucial remaining question is how the nerve induces the trap for randomly diffusing ACh receptors. In this study we examined the effect of various glycosaminoglycans in the culture medium on the nerve-induced receptor accumulation and found that heparin and heparan sulfate partially inhibited nerveinduced receptor accumulation, but similar molecules, chondroitin sulfate type $A$ and type $C$, did not. By chemical modification of heparin we also showed that $\mathrm{N}$-sulfate residues and a large-molecular-weight molecule are essential for this inhibitory effect. Heparin did not affect $\mathrm{ACh}$ receptor clustering (hot-spot formation) in myocytes cultured without nerve. By changing the time and duration of heparin application, we found that heparin was effective in inhibiting nerveinduced receptor accumulation only when it was present in the culture medium during the period that neurites are actively forming contact with muscle membrane.
\end{abstract}

During the early period of neuromuscular junction formation ACh receptors accumulate at the site of nerve contact. In Xenopus nerve-muscle cultures this is at least partly due to lateral migration of receptors in the muscle membrane (Anderson and Cohen, 1977; Anderson et al., 1977). We have further shown that receptor accumulation primarily results from "diffusion trapping" (Kuromi et al., 1985; Kuromi and Kidokoro, 1984a, b; Kidokoro et al., 1986): Namely, randomly diffusing ACh receptors in the muscle membrane come into contact with the nerve-induced trap where their migration is practically stopped, resulting in high receptor density regions at the subsynaptic membrane. The concept of the diffusion trap to explain receptor accumulation at the neuromuscular junction was first proposed by Edwards and Frisch (1976). Its plausibility was further confirmed by Chao et al. (1981). In chick cultures, however, preferential insertion of new receptors at the junctional region has been found to be the major mechanism for receptor accumulation (Role et al., 1985).

\footnotetext{
Received Apr. 14, 1988; revised Sept. 23, 1988; accepted Nov. 2, 1988.

We wish to thank Drs. A. Grinnell, I. Chow, S. Young, D. Schubert, and J. Rohrbough for their comments on the manuscript. This work is supported by NIH Research Grant (NS 23753) and a grant from the Muscular Dystrophy Association of America to Y.K.

Correspondence should be addressed to Yoshi Kidokoro at the above address.
}

Copyright (C) 1989 Society for Neuroscience $0270-6474 / 89 / 051555-07 \$ 02.00 / 0$
Receptor aggregation occurs under various conditions. Muscle cells cultured alone have discrete receptor clusters (hot spots) on the surface membrane. Nonspecific substances, such as silk thread (Jones and Vrbova, 1974) or positively charged latex beads (Peng et al., 1981), can cause ACh receptor accumulation at the contact area. Electric fields also induce receptor aggregation at the cathodal pole (Orida and Poo, 1978). Thus, it is clear that the muscle cell by itself is capable of forming and maintaining receptor aggregates.

Many of the "hot spots" in cultured muscle cells occur in association with fragments of basement membrane (Anderson and Fambrough, 1983). In the adult animal, aggregates of ACh receptors occur at the old synaptic sites after regeneration of new muscle fibers in a damaged muscle, even in the absence of the nerve terminal (Burden et al., 1979). In this case, the basement membrane that remains after nerve and muscle degeneration is the most likely candidate to carry information about the synaptic site. Some identified molecules have been localized specifically to the synaptic basement membrane (Sanes and Hall, 1979; Anderson and Fambrough, 1983; Bayne et al., 1984; Covault and Sanes, 1985; Rieger et al., 1985; Chieu et al., 1986; Moor and Walsh, 1986; Sanes et al., 1986; Reist et al., 1987). Although the function of most of thesc molcculcs is not known, some may play a role as a trap for ACh receptors.

In the past several years, progress has been made in the isolation and characterization of molecules that promote $\mathrm{ACh}$ receptor accumulation (Christian et al., 1978; Podleski et al., 1978; Bauer et al., 1981; Usdin and Fischbach, 1986; Barald et al., 1987). To date, agrin (Godfrey et al., 1984; Wallace, 1986; Nitkin et al., 1987) is the best characterized molecule. Agrin is isolated from the Torpedo electric organ and increases the number of receptor clusters in chick muscle cultures. Antibodies against agrin stain the basement membrane at the neuromuscular junction of frog, chicken, and ray (Reist et al., 1987). It is postulated that agrin is released at the motor nerve terminal and is incorporated in nascent synaptic basal lamina, and that it exerts its effect on $\mathrm{ACh}$ receptors and other molecules (Nitkin et al., 1987).

Another molecule, heparan sulfate proteoglycan, is localized to the basement membrane at the neuromuscular junction (Anderson and Fambrough, 1983; Bayne et al., 1984). Cholinergic vesicles contain heparan sulfate-related proteoglycan, chondroitin sulfate, which becomes exposed on the presynaptic terminal during neurotransmitter release (Kelly et al., 1983; Carlson and Wight, 1987). Thus, heparan sulfate proteoglycan could serve either as a signal or as the receptor for the signal causing $\mathrm{ACh}$ receptor accumulation. To gain an insight into this process, we included various glycosaminoglycans and their derivatives in 
the medium of Xenopus nerve-muscle cultures and examined the effect on nerve-induced receptor accumulation. If heparan sulfate proteoglycan is involved in receptor accumulation, then the similar soluble molecule may interfere with this signaling process, for example, by binding to the normal heparan sulfate proteoglycan receptor.

We found that heparin and heparan sulfate in the culture medium inhibited nerve-induced receptor accumulation, but chondroitin sulfates did not. Heparin was effective in inhibiting nerve-induced receptor accumulation only when it was present in the culture medium during the period that neurites are actively forming contact with the muscle membrane.

\section{Materials and Methods}

Cultures. Culturing procedures were the same as those published previously (Anderson et al., 1977; Kidokoro et al., 1980). Briefly, the dorsomedial portion of Xenopus embryos at stage 23-25 (Nieuwkoop and Faber, 1957) was dissected out with a pair of needles. The tissue was then treated with $1 \mathrm{mg} / \mathrm{ml}$ collagenase (Worthington) in low-Ca'+ salinc for about $10 \mathrm{~min}$. After this treatment myotomal tissue was easily separated from epithelial, endodermal, notochordal, and neural tube lissue. The muscle tissue from approximately 20 embryos was pooled and further dissociated into individual cells in $\mathrm{Ca}^{2+}$ - and $\mathrm{Mg}^{2+}$-free saline for about $10 \mathrm{~min}$. These dissociated myocytes were distributed into 4 culture dishes. One or $2 \mathrm{~d}$ later, about 20 neural tubes were isolated from a new batch of embryos at stage $23-25$ by the collagenase treatment, pooled, further dissociated as described above, and added to 4 muscle cultures. The distribution of ACh receptor clusters was examined a day or two later.

In some experiments neurons were plated first and myocytes were added after neurons had extended neurites in 1- or 2-d-old cultures. Usually myocytes attached to the substrate within $5 \mathrm{hr}$. In this manner nerve-muscle contacts were established in a relatively short period of time.

Visualization of $A C h$ receptor clusters. Distribution of $\mathrm{ACh}$ receptor clusters was visualized by using tetramethyl rhodamine conjugated $\alpha$-bungarotoxin (TMR- $\alpha \mathrm{BT}$ ). Nerve-muscle cultures were exposed to 2 $\mu \mathrm{M}$ TMR- $\alpha \mathrm{BT}$ for $1 \mathrm{hr}$ at room temperature, and the staining medium was washed out with the normal culture medium. These cultures were observed with a fluorescence microscope (IM35, Zeiss) with a $40 \times$ water-immersion objective lens. For photography, Tri-X film (Kodak) was used. The exposure time for fluorescence microscopy was 40-60 sec. The film was developed with Microdol (Kodak, diluted 1:3) for 6 $\min$ at $22^{\circ} \mathrm{C}$.

Criteria for identification of nerve-induced receptor accumulation. When large clusters of ACh receptors (about $1-5 \mu \mathrm{m}$ ) or double band structures (see figure 2 in Kidokoro et al., 1980) were associated with the nerve contact area, the myocyte was classified as $(+)$. Usually in these cases receptor clusters outside the nerve contact region were not observed. When a few speckles of ACh receplor clusters were associaled with the nerve contact path or when the nerve contacted the muscle along the edge, it was classified as $( \pm)$ for the following reasons: Small speckles were often scattered over the muscle surface, and it is quite likely that a few of them were associated with the nerve contact path, even though the nerve was not inducing ACh receptor clusters; further, myocytes without nerve contacts often had receptor clusters along the edge, and it was difficult to distinguish nerve-induced clusters from those normally found at the edge. When there were no ACh receptor clusters along the nerve, the myocyte was classified as (-).

Counting myocytes with nerve-induced receptor clusters. First, a myocyte with clear nerve contacts was chosen under phase-contrast optics (40x water immersion). Those cells that had nerve contacts only at the edge were avoided. Second, the optics were switched to fluorescence microscopy and receptor accumulation was assayed according to the criteria described above. When a neuron contacted many myocytes, only one of them was examined for receptor accumulation. No fewer than 21 myocytes were assayed in one culture dish, and the percentage of myocytes with receptor accumulation was determined. The percentage of myocytes with nerve-induced receptor clusters is the number of cells belonging to a $(+)$ category divided by the total number of cells observed and multiplied by 100 .

The percentage of inhibition was defined as $(A-B) / A(\%)$, where $A$ is the percentage of myocytes with nerve-induced receptor accumulation in control sister cultures and $B$ is that of test cultures.

Digestion of heparin with heparinase. Low-molecular-weight heparin (Sigma, 4000-6000 MW) was digested by heparinase (Sigma). The digestion procedure was based on the protocol described by Linker and Hovingh (1977). Briefly, heparin $(1 \mathrm{mg} / 40 \mu$ l distilled water), $16 \mathrm{U}$ of heparinase in $160 \mu \mathrm{l}$ sodium acetate $(0.1 \mathrm{~m})$ and $30 \mu \mathrm{l}$ of $10 \mathrm{~mm}$ calcium acetate were mixed, and the final volume was made up to $0.3 \mathrm{ml}$ with $0.1 \mathrm{~m}$ sodium acetatc. This solution was incubated at $30^{\circ} \mathrm{C}$ for $48 \mathrm{hr}$. An effective cleavage of heparin was examined spectrophotometrically. Formation of $\alpha, \beta$ unsaturated uronides, which have a strong absorption maximum at $232 \mathrm{~nm}$, was used to assay the effective digestion. An aliquot of $50 \mu \mathrm{l}$ was withdrawn from the solution and added to $1.45 \mathrm{ml}$ of $30 \mathrm{~mm} \mathrm{HCl}$ and assayed in a spectrophotometer. The remaining 250 $\mu l$ of the solution was treated for $5 \mathrm{~min}$ at $100^{\circ} \mathrm{C}$ to inactivate heparinase. This process did not affect the activity of heparin, as similarly treated heparin (nondigested control) was effective in inhibiting nerve-induced receptor accumulation (see Fig. $1 B$ ). With this assay heparin was found to be effectively digested to di-, tetra-, and hexasaccharides. A mixture of these saccharides was used to test the effect on nerve-induced receptor accumulation. It has been reported that more than $85 \%$ of the heparin is digested in this protocol (Linker and Hovingh, 1977).

Biochemicals. Two types of heparin, low molecular weight $(4000$ $6000)$ and regular $(15,000-25,000)$, heparan sulfate, de- $N$-sulfated heparin, chondroitin sulfate type $A$ and $C$, and heparinase were all purchased from Sigma Chemical Co. (St. Louis, MO).

Area measurement of hot spots. The image on the $35 \mathrm{~mm}$ film was enlarged, and the area was measured on a digitizer (Summa Sketch) using an area-measuring program (Jandel Scientific, Sausalito, CA) running on an IBM PC-XT. Some hot spots were very small (speckles), and it was too difficult to measure their area; therefore, we only measured hot spots larger than $43 \mu \mathrm{m}^{2}$.

\section{Results}

To examine the effect of neural cells on ACh receptor clustering, muscle tissue was dissected from embryos at stage 23-25 and the myocytes were dissociated in $\mathrm{Ca}^{2+}, \mathrm{Mg}^{2+}$-free saline. Neuronal cells were added after the myocytes were in culture for 1 or $2 \mathrm{~d}$, and the distribution of receptor clusters on the myocytes was examined 1 or $2 \mathrm{~d}$ later by staining with TMR- $\alpha \mathrm{BT}$. A total of 1707 myocytes with nerve contact was observed in 55 normal cultures. Some $62.6 \pm 7.9 \%$ (mcan $\pm \mathrm{SD} ; n=55$, number of cultures) of the myocytes had clear nerve-induced receptor accumulation; $9.2 \pm 5.6 \%$ of them belonged to the $( \pm)$ category, the balance $(28.4 \pm 7.2 \%)$ being negative. These values are similar to those published previously (Kidokoro et al., 1986). Since the neurons we used in these experiments were obtained by dissociating whole neural tubes at stage $23-25$, they were a mixture of various nerve cell types, such as molvneurons and Rohon-Beard cells. Because only cholinergic neurons induce receptor accumulation (Cohen and Weldon, 1980; Kidokoro et al., 1980), it is likely that some myocytes were contacted by noncholinergic neurons and did not show nerve-induced receptor accumulation.

\section{Heparin and heparan sulfate inhibited nerve-induced $A C h$ receptor accumulation but chondroitin sulfate type $A$ and $C$ did not.}

To assay the effect of glycosaminoglycans on ACh receptor accumulation, low-molecular-weight heparin (4000-6000 MW) was included in the medium at a final concentration of $250 \mu \mathrm{g} /$ $\mathrm{ml}$ when neurons were added to established muscle cultures. After various periods of incubation (20.5-49 hr), cultures were stained with TMR- $\alpha \mathrm{BT}$, and the receptor distribution was examined. Three sets of data are shown in Figure $1 \mathrm{Aa}$. The incubation period $(49,20.5$, and $22.5 \mathrm{hr}$ ) is depicted at the bottom of each set of columns. Fach set contains 2 control and 2 test 

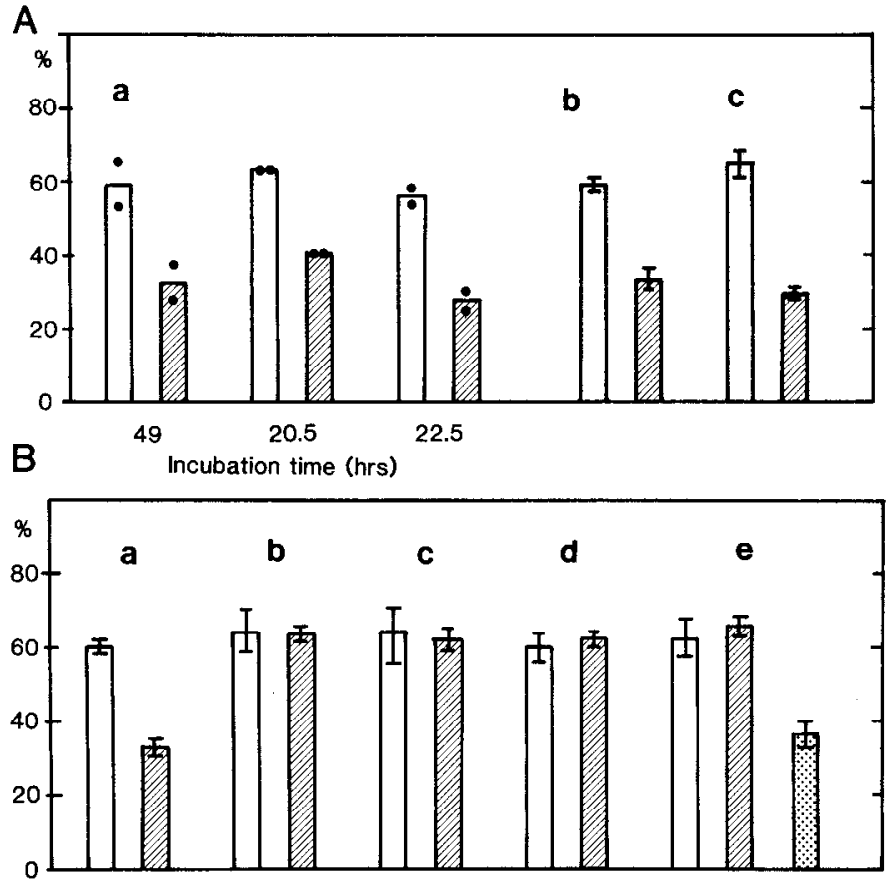

Figure 1. A, Effect of low-molecular-weight heparin on nerve-induced receptor accumulation. The percentage of myocytes with nerve-induced receptor accumulation is plotted on the ordinate. Blank columns are for control and shaded columns are for heparin-treated cultures. No less than 21 nerve-contacted myocytes were assayed for receptor accumulation in each culture, and in one set of experiments 2 control cultures and 2 test cultures were used. $a$, Three sets of cultures. Test cultures were incubated with $250 \mathrm{\mu g} / \mathrm{ml}$ low-molecular-weight heparin for the period indicated at the bottom. Note that the extent of inhibition is not dependent on the incubation time. $b$, Pooled data from $a$ (6 cultures). The bar at the top of each column indicates SFM. c, Similar data for regular heparin $(250 \mu \mathrm{g} / \mathrm{ml})$. Data from 6 cultures were pooled. $B$, Effect of various glycosaminoglycans on nerve-induced receptor accumulation. Blank columns are for control and shaded columns are for test cultures. The bar at the top of each column indicates the SEM. $a$, Heparan sulfate $(250 \mu \mathrm{g} / \mathrm{ml}) ; b$, chondroitin sulfate, type A $(250 \mu \mathrm{g} / \mathrm{ml})$. $c$, chondroitin sulfate, type C (250 $\mathrm{\mu g} / \mathrm{ml}) ; d$, de- $N$-sulfated heparin $(250$ $\mu \mathrm{g} / \mathrm{ml}$ ); $e$, heparinase-digested heparin (low-molecular-weight heparin, $250 \mu \mathrm{g} / \mathrm{ml}$, before digestion). The third dotted column is for nondigested heparin. Heparin was treated in exactly the same way as in the digesting procedures except that heparinase was not added.

cultures. In all cases the percentage of myocytes with nerveinduced receptor accumulation $(32.6,40.7,27.7)$ was smaller than the corresponding control $(59.3,63.1,56.0)$. There was no dependency of the inhibitory effect on the incubation period among these examples or among other sets of experiments (summarized data are shown in Fig. 5, solid bars). On pooling all data obtained in the same experimental protocol, the value was $33.7 \pm 7.0 \%(n=6$, number of cultures) in test cultures and $59.5 \pm 5.4 \%(n=6)$ in control (Fig. $1 A b)$. These values are significantly different ( $p=0.001$, Student's $t$ test). The mean percentage of inhibition is $43.9 \pm 7.3 \%$ ( $n=3$, number of sets).

Thus, $250 \mu \mathrm{g} / \mathrm{ml}$ low-molecular-weight heparin partially inhibited nerve-induced $\mathrm{ACh}$ receptor accumulation. Even in these cultures, $33.7 \%$ of the nerve-contacted myocytes displayed nerveinduced receptor accumulation. The extent of nerve-induced receptor accumulation in those cells was similar to that in control cultures (Fig. 2, $A, C$ ). Heparin appears to reduce the number of myocytes with characteristic nerve-induced receptor accumulation, but heparin does not appear to inhibit the extent of receptor accumulation in those myocytes that exhibited nerveinduced receptor accumulation. An example of nerve-muscle contact without associated receptor clusters is depicted in Figure $2, B, D$.

It is possible that heparin selectively kills cholinergic neurons and thereby reduces the percentage of myocytes with receptor accumulation, although the morphology of neurons and muscle cells grown in the presence of heparin was indistinguishable from that in the control culture. This possibility can be eliminated based on the following observations. First, we performed an experiment in which neurons were plated with low-molecular-weight heparin $(250 \mu \mathrm{g} / \mathrm{ml})$ for $24 \mathrm{hr}$. The culture medium was then replaced with normal medium and, at the same time, myocytes were added. Approximately $1 \mathrm{~d}$ later, the nerve-induced receptor accumulation was assayed. The percentage of myocytes with nerve-induced receptor accumulation was 56.6 $\pm 2.5 \%(n=3)$ for heparin-treated cultures and $53.1 \pm 4.1 \%$ $(n=4)$ for controls. Thus, in these cultures, heparin did not inhibit nerve-induced receptor accumulation. If heparin had selectively killed cholinergic neurons, we would expect to have found an inhibitory effect of heparin in these cultures. Second, in nerve-muscle cultures ( 24 or more hours of co-incubation), there were $633 \pm 96(n=7)$ neurons in control cultures and $580 \pm 98(n=5)$ neurons in heparin-treated cultures. If the decrease in the number of myocytes with nerve-induced receptor accumulation were solely due to sclcctive death of cholinergic neurons, the total number of neurons in heparin-treated cultures would be expected to be about $70 \%$ of control. Therefore, it is unlikely that cholinergic neurons were selectively killed in heparin-treated cultures.

Regular heparin (MW 15,000-25,000) at $250 \mu \mathrm{g} / \mathrm{ml}$, tested in the same manner, had an inhibitory effect similar to that of the $250 \mu \mathrm{g} / \mathrm{ml}$ low-molecular-weight heparin (Fig. 1AC). The percentage of myocytes with receptor accumulation was $29.7 \pm$ $3.7 \%(n=5)$ for treated cultures and $64.9 \pm 6.1 \%(n=4)$ for controls. The percentage of inhibition was $54 \%$. Since the molecular weight of regular heparin is approximately 4 times larger than that of the low-molecular-weight heparin, the molar concentration of regular heparin was about one-fourth of that of low-molecular-weight heparin. When we compared the percentage of inhibition by regular heparin with the same concentration of low-molecular-weight heparin, the former was 2-3 times more potent.

The effect of heparin is only partial. If, for some reason, heparin cannot reach the substrate-side surface of the muscle and cannot inhibit receptor accumulation at the substrate surface, then partial inhibition could be explained. We tested this idea by distinguishing receptor clusters on the substrate side from those on the upper side. We found that, even in the presence of heparin or heparan sulfate, some myocytes had nerve-induced receptor clusters on the upper surface $(57 \%$ of nerve-induced receptor accumulation occurred on the upper side of muscle cells). Therefore, the partial inhibition by heparin is unlikely to be due to inaccessibility of the substrate surface.

Heparan sulfate $(250 \mu \mathrm{g} / \mathrm{ml})$ also inhibited the percentage of myocytes with nerve-induced receptor accumulation (Fig. $1 B a$ ). Pooled results were $33.0 \pm 6.1 \%(n=6)$ for heparan sulfatetreated cultures and $60.3 \pm 4.6 \%(n=6)$ in controls. These 2 values are significantly different at $p=0.001$. The percentage of inhibition was $45 \%$ (Fig. $1 B a$ ).

In contrast, $250 \mu \mathrm{g} / \mathrm{ml}$ chondroitin sulfate type A (Fig. $1 B b$ ) and type $\mathrm{C}$ (Fig. $1 B C$ ) did not have an inhibitory effect. Pooled 

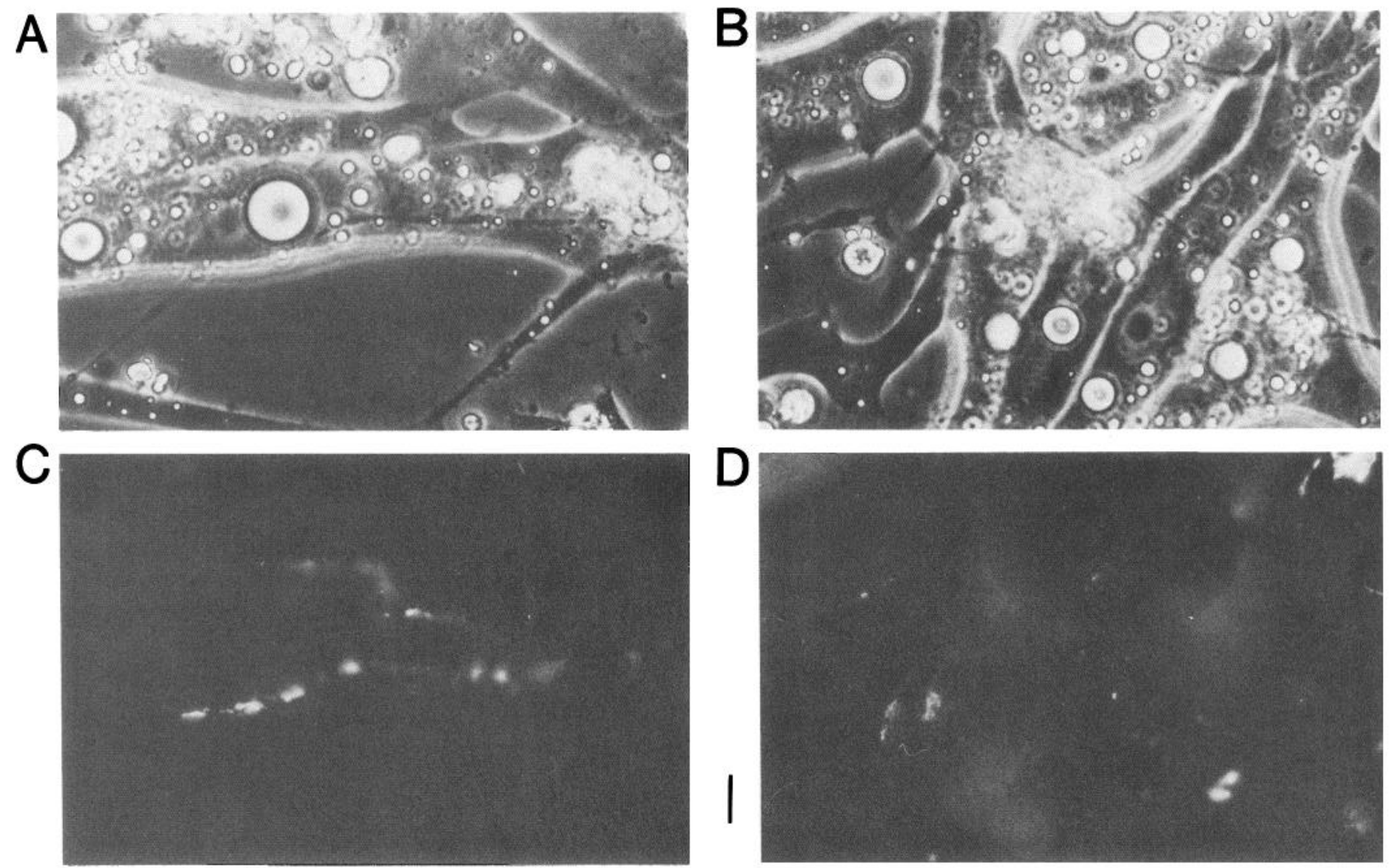

Figure 2. Distribution of ACh receptor clusters in Xenopus myocyte cultures in the presence of regular heparin (250 $\mu \mathrm{g} / \mathrm{ml}) . A$ and $B$ are phasecontrast and $C$ and $D$ are corresponding fluorescence micrographs showing the distribution of $A C h$ receptor clusters. In $A$ and $C$, receptors localized along the path of nerve contact; in $B$ and $D$, receptor clusters are not associated along the nerve contact. The vertical bar at the center corresponds to $10 \mu \mathrm{m}$.

data gave $63.8 \pm 4.7 \%(n=6)$ for chondroitin sulfate (type A)treated cultures and $64.3 \pm 13.1 \%(n=4)$ for controls. Those for chondroitin sulfate (type C) were $62.4 \pm 7.9 \%(n=7)$ and $63.3 \pm 15.0 \%(n=4)$ for controls. These values for treated cultures are not significantly different from control cultures.

Heparin and heparan sulfate are similar to chondroitin sulfate except that the latter does not have $N$-sulfate residues while the former molecules do. To examine whether the $N$-sulfate residues play a role in this inhibitory effect, we used heparin without $N$-sulfate residues. As shown in Figure $1 B d$, this form of the molecule $(250 \mu \mathrm{g} / \mathrm{ml})$ did not have the inhibitory effect. The percentage of myocytes with nerve-induced receptor accumulation for treated cultures was $62.5 \pm 4.3 \%(n=6)$ and $60.3 \pm$ $8.9 \%(n=6)$ in the control. These values are not different. Thus, it appears that $N$-sulfate residues are important in heparin's inhibitory action.

Heparinase digests heparin into smaller saccharides. When low-molecular-weight heparin $(250 \mu \mathrm{g} / \mathrm{ml})$ was digested into di-, tetra-, and hexasaccharides (see Materials and Methods), a mixture of these oligosaccharides no longer had an inhibitory effect. Two kinds of control experiments were carried out. In one, heparin $(250 \mu \mathrm{g} / \mathrm{ml})$ was treated with the same protocol for digestion, except heparinase was not added (nondigested control). The other was a regular control with $250 \mu \mathrm{g} / \mathrm{ml} \mathrm{low}-\mathrm{mo}-$ lecular-weight heparin (control).

The pooled percentage of myocytes with nerve-induced receptor accumulation was $66.0 \pm 2.5 \%(n=4)$ for digested hep- arin (shaded column in Fig. $1 B e$ ), $62.7 \pm 5.1 \%$ for control (blank column in Fig. $1 \mathrm{Be})$, and $36.3 \pm 3.6 \%(n=4)$ for nondigested control $(45 \%$ inhibition, dotted column in Fig. $1 B e)$. Thus, digestion by heparinase, but not other treatment during the digestion procedure, eliminated the inhibitory effect of heparin.

The effect of low-molecular-weight heparin and heparan sulfate was dose dependent, as shown in Figure 3. The lowest effective concentration was $25 \mu \mathrm{g} / \mathrm{ml}$ for heparin. Concentrations higher than $500 \mu \mathrm{g} / \mathrm{ml}$ could not be tested because of its effect on cell viability. The potency of these 2 glycosaminoglycans was similar, and the inhibitory effect was always partial.

Reversibility of the heparin effect was tested in 4 sets of cultures. Nerve-muscle cultures were incubated for $1 \mathrm{~d}$ with medium containing low-molecular-weight heparin $(250 \mu \mathrm{g} / \mathrm{ml})$. Receptor staining was done when the culture medium was switched to the normal medium without heparin. After about $24 \mathrm{hr}$ in normal medium, the percentage of myocytes with nerve-induced receptor accumulation was assayed. The percentage of inhibition varied between 2 and $54 \%$ in the 4 sets of cultures. On pooling the data, the percentage of myocytes with nerve-induced receptor accumulation in heparin-treated cultures was $48.6 \pm$ $16.0 \%(n=6)$ and $65.2 \pm 4.7 \%(n=7)$ in control cultures. The percentage of inhibition was $25 \%$. Thus, some inhibition was still observed. The recovery seemed partial after $24 \mathrm{hr}$. It is plausible that neurites grew after the normal medium was restored and developed nerve-induced receptor accumulated receptor accumulation de novo, even though heparin blocked re- 


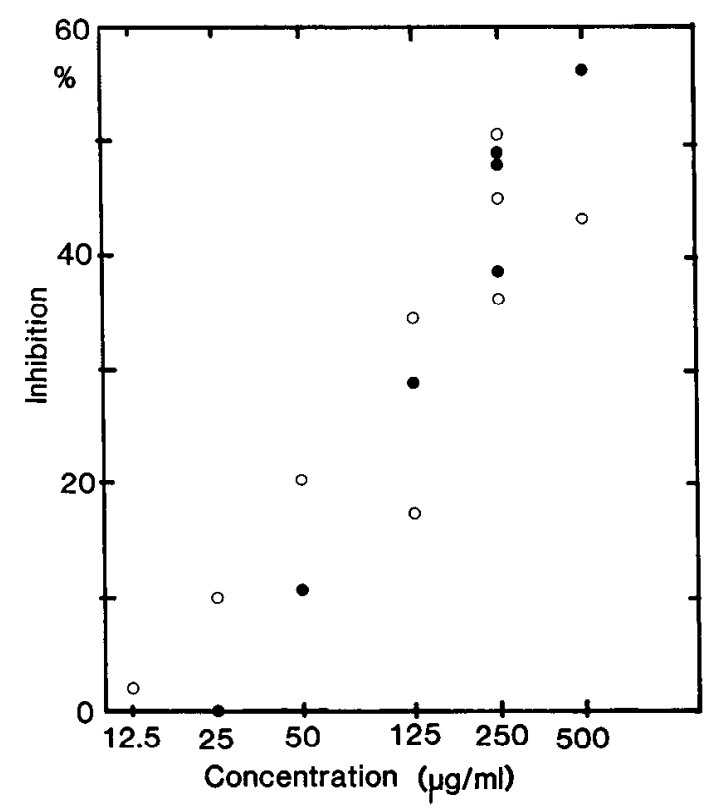

Figure 3. Dose-response relation for low-molecular-weight heparin (open circles) and heparan sulfate (filled circles). The percentage of inhibition is defined under Materials and Methods. The concentration is plotted logarithmically on the abscissa.

ceptor accumulation irreversibly at the nerve-muscle contacts that had formed in the presence of heparin. To test this possibility we identified 54 nerve-contacted myocytes without nerveinduced receptor accumulation in 4 cultures shortly after removal of heparin (low molecular weight) from the medium (the percentage of myocytes with nerve-induced receptor accumulation was $34.3 \pm 7.6 \%$ after heparin treatment, indicating the inhibitory effect of heparin). We then reexamined those nerve contacts a day later and found that a great majority of these contacts (46 contacts, $85 \%$ ) did not develop nerve-associated receptor clusters and only 6 nerve-contacted myocytes exhibited receptor accumulation along the path of nerve contact (11\%). If the heparin effect were reversible, we would expect that about $40 \%$ of these contacts to develop receptor accumulation. Therefore, the effect of heparin appears to be mostly irreversible.

\section{Heparin does not affect hot-spot formation in muscle cultures}

Myocytes cultured without neural cells did not have recognizable hot spots shortly after plating (about $5 \mathrm{hr}$ ) but did develop hot spots within $24 \mathrm{hr}$. Thus, these hot spots were formed de novo in culture. We tested the effect of heparin in hot-spot formation. Myocytes were plated in the presence of low-molecular-weight heparin $(250 \mu \mathrm{g} / \mathrm{ml})$. These cultures were stained 48 hr later and the number, as well as area, of hot spots were measured. As shown in Figure 4, heparin and heparan sulfate did not affect the number of hot spots in muscle cultures. The area of hot spots (average of hot spots $>43 \mu \mathrm{m}^{2}$ ) was measured in 82 cells in 4 cultures treated with heparin and in 100 cells in 4 control cultures. These values were $72.3 \pm 36.3 \mu \mathrm{m}^{2}(n=82)$ in heparin-treated cultures and $76.1 \pm 56.0 \mu \mathrm{m}^{2}(n=100)$ in control cultures. Therefore, heparin did not affect the ability of myocytes to cause receptor aggregation.

\section{Timing and duration of the heparin-sensitive period}

It is likely that heparin and heparan sulfate affect the signaling process between nerve and muscle during receptor accumula-

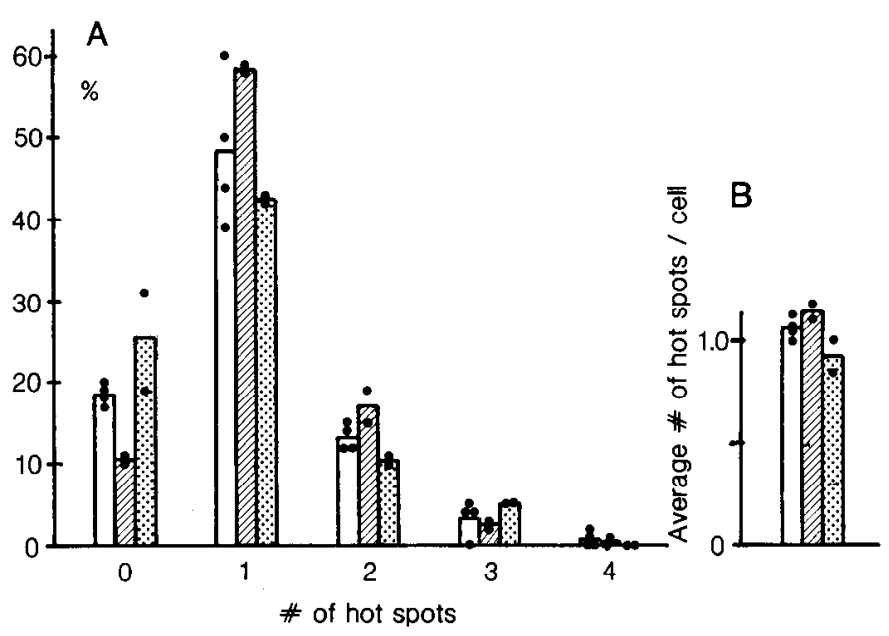

Figure 4. Effect of low-molecular-weight heparin $(250 \mu \mathrm{g} / \mathrm{ml})$ and heparan sulfate $(250 \mu \mathrm{g} / \mathrm{ml})$ on receptor cluster formation (hot-spot formation) in muscle cultures without neuronal cells. $A$, Percentage of myocytes with a given number of hot spots is plotted on the ordinate. The number of hot spots is plotted on the abscissa. The blank columns are for the control; the shaded columns, heparan sulfate-treated cultures; and dotted columns, heparin-treated cultures. Each point represents an average of the percentage in one culture. In each culture more than 76 myocytes were assayed. $B$, Average numbers of hot spots per cell. The blank columns are the control; shaded columns, heparan sulfate-treated cultures; and dotted columns, heparin-treated cultures.

tion. Hence, by examining the timing and duration of the heparin or heparan sulfate effect, we might be able to determine the timing of the induction signaling process. In most cases, these glycosaminoglycans were added at the time of addition of neurons to the muscle cultures. In the following cases (summarized in Fig. 5), heparin or heparan sulfate was added to muscle cultures at different times and for different durations. Low-molecular-weight heparin $(250 \mu \mathrm{g} / \mathrm{ml})$ was added to culture medium 16.5-23.5 hr after addition of neuronal cells. Myocytes were then stained with TMR- $\alpha$ BT and observed after 20-30.5 hr of incubation with heparin. The percentage of myocytes with nerve-induced receptor accumulation was $62.0 \pm 6.4 \%(n=6)$ in heparin-treated cultures and $64.5 \pm 6.0 \%(n=6)$ in control (experiments $13-15$ in Fig. 5). Heparin did not have the inhibitory effect, nor were heparin (experiments 12 and 17 in Fig. 5) and heparan sulfate (experiment 16 in Fig. 5) effective when applied prior to addition of the nerve. In these experiments at the time of nerve addition, the culture medium containing heparin or heparan sulfate was replaced with normal medium, and nerve-induced receptor accumulation was assayed 23-48 hr later. In contrast, when $250 \mu \mathrm{g} / \mathrm{ml}$ of low-molecular-weight heparin was added $10 \mathrm{hr}$ after addition of neural cells (experiment 10), and when $250 \mu \mathrm{g} / \mathrm{ml}$ regular heparin was added $5 \mathrm{hr}$ after nerve addition (experiment 2), inhibition was evident in both cases. The percentages were $38 \%$ for the low-molecular-weight heparin-treated culturcs and 65.6 and $59.5 \%$ for controls (experiment 10 ). The percentages were $31.6 \%$ for regular heparin-treated cultures and $69.5 \%$ for the corresponding control (experiment 2). Thus, if heparin is interfering with the signaling process, the signal for receptor accumulation may be expressed transiently during this period and may no longer be expressed or effective after $16.5 \mathrm{hr}$ of coculture. When heparin was added $13.5 \mathrm{hr}$ after addition of nerve, the extent of inhibition was intermediate (experiment 11 in Fig. 5), whereas when heparin or heparan 
sulfate was present between 10 and $16.5 \mathrm{hr}$ after neural cell addition, the maximal inhibitory effect was observed. This is the period when neurites are actively extending and making new contacts with muscle cells. Thus, it appears that heparin and heparan sulfate are effective only when present in the culture medium while contact formation between nerve and muscle is in progress.

\section{Discussion}

When heparin or heparan sulfate was present in the culture medium, it partially inhibited nerve-induced receptor accumulation, but similar molecules, chondroitin sulfate type $A$ and type $\mathrm{C}$, did not inhibit nerve-induced receptor accumulation, nor did de- $N$-sulfated heparin. Digestion of heparin into smaller oligosaccharides eliminated the inhibitory effect of heparin. For a precise interpretation of these results we must wait for further elucidation of the chemical nature of nerve-muscle interactions. We were intrigued to find that heparin partially inhibited nerveinduced receptor accumulation and that receptor accumulation, when it occurred in these heparin-treated cultures, seemed identical in its extent to that in the control cultures. Although more quantitative comparisons should be made between nerve-induced receptor accumulation in the heparin-treated cultures and in controls, it appears as though there are 2 classes of neurons that are capable of causing receptor accumulation in myocytes. Only one of them has a heparin-sensitive step in the receptor accumulation process. It will be interesting to examine the effect of heparin on nerve-induced receptor accumulation in other systems, such as chick nerve-muscle cultures. In other systems, heparin might completely inhibit nerve-induced receptor accumulation or it might be completely ineffective.

We also found that heparin did not interfere with "hot-spot" formation in muscle cultures. Our interpretation of this finding is that heparin does not interfere with the interaction between the trap and ACh receptors. Other interpretations, however, are also plausible. Hot-spot formation may have a different mechanism for receptor clustering from nerve-induced receptor accumulation.

The recently isolated protein agrin is a good candidate for the signal the nerve terminal sends to the muscle cell. Agrin does not affect the appearance of new ACh receptors on the surface membrane and increases the number of receptor clusters by redistribution of old receptors (Wallace, 1987). The effects of heparin on agrin-induced receptor accumulation would be interesting to study for similarities to those on nerve-induced receptor accumulation.

Recently, Anderson (1988) demonstrated the removal of preexisting proteoglycans on the muscle surface prior to accumulation of heparan sulfate proteoglycans along the course of nerve contact. If this process is essential for receptor accumulation, heparin or heparan sulfate in the culture medium might interfere with this proteolytic process and inhibit receptor accumulation.

The heparin-sensitive step is found to appear transiently between 10 and $16.5 \mathrm{hr}$ after the addition of neuronal cells. This suggests that the signal is transmitted only during this period, either secreting the signal molecule during this period or presenting the signal on the neuronal surface. Alternatively, the signal might become inaccessible or insensitive to heparin during the period outside of this window. During early embryogenesis various growth factors play an important role for morphogenesis and many growth factors are known to bind to heparin

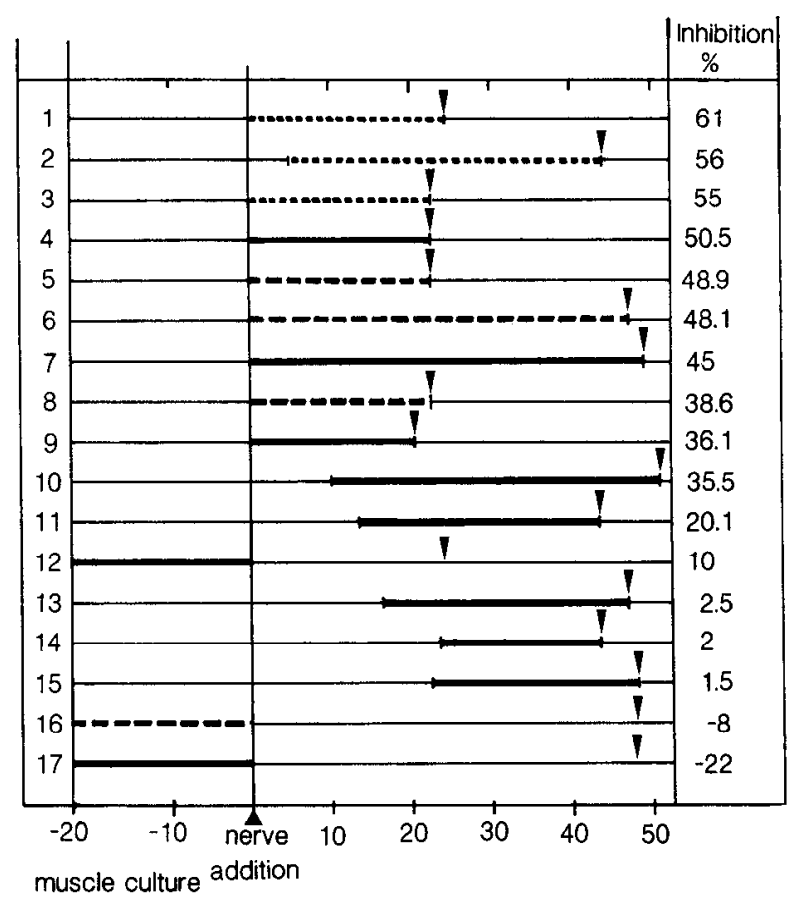

culture period (hrs)

Figure 5. Timing and duration of the heparin- or heparan sulfatesensitive period. Experiments are listed in the order of the extent of inhibition (the experiment number is given at the far left). The percentage of inhibition is defined under Materials and Methods. At the point with an upward arrow, nerve was added to 1- or 2-d-old muscle cultures. Each experiment represents data from a set of cultures that included 2 control cultures and 2 test cultures. Thick bars (broken, dotted, and solid) indicate the onset and duration of heparin or heparan sulfate application. At the end of the bar, the normal culture medium was restored, and the percentage of myocyles with nerve-induced receptor accumulation was assayed at the time indicated by downward arrows. Solid bars are for low-molecular-weight heparin $(250 \mu \mathrm{g} / \mathrm{ml})$; broken bars, heparan sulfate $(250 \mu \mathrm{g} / \mathrm{ml})$; and dotted bars, regular hep$\operatorname{arin}(250 \mu \mathrm{g} / \mathrm{ml})$.

In most cases, heparin or heparan sulfate was included in the culture medium at the time when neuronal cells were added to muscle cultures (bars starting at the time zero). These glycosaminoglycans were kept in the medium for various lengths of time ( $20-49 \mathrm{hr}$ ). Note the extent of inhibition does not depend on the length of incubation period. Three bars (experiments 12,16, and 17) are for sets of muscle cultures treated with low-molecular-weight heparin (solid bars) and with heparan sulfate (broken bar) before addition of nerve. In these 3 sets no significant inhibition was observed. Three solid bars (experiments 13-15) indicate sets of cultures in which heparin was added later than $16.5 \mathrm{hr}$ after the addition of the nerve. None of these cultures showed inhibition. Two bars (experiments 2 and 10) were for sets in which heparin was added 5 or $10 \mathrm{hr}$ after addition of nerve. Maximal inhibition was observed. Finally, experiment 11 represents a set of cultures in which low-molecular-weight heparin was added to nerve-muscle cultures $13.5 \mathrm{hr}$ after nerve addition. Only partial inhibition was observed.

(Woodland and Jones, 1988). Using heparin and related glycosaminoglycans as a tool, we might be able to approach the induction mechanism at the molecular level.

\section{References}

Anderson, M. J. (1988) Nerve-induced remodeling of muscle basal lamina during synaptogenesis. J. Cell Biol. 102: 863-877.

Anderson, M. J., and M. W. Cohen (1977) Nerve-induced and spontaneous redistribution of acetylcholine receptors on cultured muscle cells. J. Physiol. (Lond.) 268:757-773.

Anderson, M. J., and D. M. Fambrough (1983) Aggregates of acetylcholine receptors are associated with plaques of a basal lamina hep- 
aran sulphate proteoglycan on the surface of skeletal muscle fibers. J. Cell Biol. 97: 1396-1411.

Anderson, M. J., M. W. Cohen, and E. Zorychta (1977) Effects of innervation on the distribution of acetylcholine receptors on cultured muscle cells. J. Physiol. (Lond.) 268: 731-756.

Barald, K. F., G. D. Phillips, J. C. Jay, and I. F. Mizukami (1987) A component in mammalian muscle synaptic basal lamina induces clustering of acetylcholine receptors. Prog. Brain Res. 71: 397-408.

Bauer, H. C., M. P. Daniels, P. A. Pudimat, L. Jacques, H. Sugiyama, and C. N. Christian (1981) Characterization and partial purification of aneural factor which increases acetylcholine receptor aggregation on cultured muscle cells. Brain Res. 209: 395-404.

Bayne, E. K., M. J. Anderson, and D. M. Fambrough (1984) Extracellular matrix organization in developing muscle: Correlation with acetylcholine receptor aggregates. J. Cell Biol. 99: 1486-1501.

Burden, S. J., P. B. Sargent, and U. J. McMahan (1979) Acetylcholine receptors in regenerating muscle accumulate at original synaptic sites in the absence of nerves. J. Cell Biol. 82: 412-425.

Carlson. S. S., and T. W. Wight (1987) Nerve terminal anchorage protein 1 (TAP-1) is a chondroitin sulphate proteoglycan: Biochemical and electronmicroscopic characterization. J. Cell Biol. 105:30753086.

Chao, N.-M., S. H. Young, and M.-M. Poo (1981) Localization of cell membrane components by surface diffusion into a "trap." Biophys. J. 36: $138-153$.

Chieu, A. Y., W. D. Matthew, and P. Patterson (1986) A monoclonal antibody which blocks the activity of a neurite regeneration promoting factor: Studies on the binding site and its localization in vivo. J. Cell Biol. 102: 1383-1398.

Christian, C. N., M. P. Daniels, H. Sugiyama, Z. Vogel, I. Jacques, and P. G. Nelson (1978) A factor from neurons increases the number of acetylcholine receptor aggregates on cultured muscle cells. Proc. Natl. Acad. Sci. USA 75: 4011-4015.

Cohen, M. W., and P. R. Weldon (1980) Localization of acetylcholine receptors and synaptic ultrastructure at nerve-muscle contacts in culture: Dependence on nerve type. J. Cell Biol. 86: 388-401.

Covault, J., and J. R. Sanes (1985) Neural cell adhesion molecule (NCAM) accumulates in denervated and paralysed skeletal muscle. Proc. Natl. Acad. Sci. USA 82: 4544-4548.

Edwards, C., and H. L. Frisch (1976) A model for the localization of acetylcholine receptors at the muscle endplate. J. Neurobiol. 7:377381.

Godfrey, E. W., R. M. Nitkin, N. E. Reist, B. G. Wallace, and U. J. McMahan (1984) Components of Torpedo electric organ and muscle that cause aggregation of acetylcholine receptors on cultured muscle cells. J. Cell Biol. 99: 615-627.

Jones, R., and G. Vrbova (1974) Two factors responsible for the development of denervation hypersensitivity. J. Physiol. (Lond.) 236: 517-538.

Kelly, R. B., K. M. Buckley, T. L. Burgess, S. S. Carlson, P. Caroni, J. E. Hooper, A. Katzen, H.-P. Moore, S. R. Pfeffer, and T. A. Schroer (1983) Membrane traffic in neurons and peptide-secreting cells. Cold Spring Harbor Quant. Biol. 48: 697-705.

Kidokoro, Y., and B. Brass (1985) Redistribution of acetylcholine receptors during neuromuscular junction formation in Xenopus cultures. J. Physiol. (Paris) 80: 212-220.

Kidokoro, Y., M. J. Anderson, and R. Gruener (1980) Changes in synaptic potential properties during acetylcholine receptor accumulation and neurospecific interaction in Xenopus nerve-muscle culture. Dev. Biol. 78: 464-483.

Kidokoro, Y., B. Brass, and H. Kuromi (1986) Concanavalin A prevents acetylcholine receptor redistribution in Xenopus nerve-muscle cultures. J. Neurosci. 6: 1941-1951.
Kuromi, H., and Y. Kidokoro (1984a) Nerve disperses pre-existing acetylcholine receptor clusters prior to induction of receptor accumulation in Xenopus muscle cultures. Dev. Biol. 103: 53-61.

Kuromi, H., and Y. Kidokoro (1984b) Denervation disperses acetylcholine receptor clusters at the neuromuscular junction in Xenopus cultures. Dev. Biol. 104: 421-427.

Kuromi, H., B. Brass, and Y. Kidokoro (1985) Formation of acetylcholine receptor clusters at neuromuscular junction in Xenopus cultures. Dev. Biol. 109: 165-176.

Linker, A., and P. Hovingh (1977) The uses of degradative enzymes as tools for identification and structural analysis of glycosaminoglycans. Fed. Proc. 36: 43-46.

Moor, S. E., and F. S. Walsh (1986) Nerve-dependent regulation of neural cell adhesion molecule expression in skeletal muscle. J. Neurosci. 18: 499-505.

Nieuwkoop, P. D., and J. Faber (1967) Normal Table of Xenopus laevis (Daudin). Elsevier-North Holland, Amsterdam.

Nitkin, R. M., M. A. Smith, C. Magill, J. R. Fallon, Y.-M. Yao, B. G. Wallace, and U. J. McMahan (1987) Identification of Agrin, a synaptic organizing protein from Torpedo electric organ. J. Cell Biol. 105. 2471-2478.

Orida, N., and M.-M. Poo (1978) Electrophoretic movement and localization of acetylcholine receptors in the embryonic muscle cell membrane. Nature 275: 31-35.

Peng, H. B., P.-C. Cheng, and P. W. Luther (1981) Formation of ACh receptor clusters induced by positively charged latex beads. Nature 292: 831-834.

Podleski, T. R., D. Axelrod, R. Raudin, I. Greenberg, M. M. Johnson, and M. M. Salpeter (1978) Nerve extract induces increase and redistribution of acetylcholine receptor on cloned muscle cells. Proc. Natl. Acad. Sci. USA 75: 2035-2039.

Reist, N. E., C. Magill, and U. J. McMahan (1987) Agrin-like molecules at synaptic sites in normal, denervated and damaged skeletal muscles. J. Cell Biol. 105: 2457-2469.

Rieger, F., M. Grumet, and G. M. Edelman (1985) N-CAM at the vertebrate neuromuscular junction. J. Cell Biol. 101: 285-293.

Role, L. W., V. R. Mattosian, R. J. O'Brien, and G. D. Fischbach (1985) On the mechanism of acetylcholine receptor accumulation at newly formed synapses on chick myotubes. J. Neurosci. 5: 2197-2204.

Sanes, J. R., and Z. W. Hall (1979) Antibodies that bind specifically to synaptic sites on muscle fiber basal lamina. J. Cell Biol. 83: 357370.

Sanes, J. R., M. Schachner, and J. Covault (1986) Expression of several adhesive macromolecules (N-CAM, L1, J1, NILE, uvomorulin, laminin, fibronectin and a heparan sulphate proteoglycan) in embryonic, adult and denervated adult skeletal muscle. J. Cell Biol. 102: 420431.

Usdin, T. B., and G. D. Fischbach (1986) Purification and characterization of a polypeptide from chick brain that promotes the accuminlation of acetylcholine receptors in chick myotubes. J. Cell Biol. 103: 493-507.

Wallace, B. G. (1986) Aggregating factor from Torpedo electric organ induces patches containing acetylcholine receptors; acetylcholinesterase and butyrylcholinesterase on cultured myotubes. J. Cell Biol. 102: 783-794.

Wallace, B. G. (1987) Agrin-induced acetylcholine receptor aggregation: $\mathrm{Ca}^{++}$dependence, inhibition by phorbol ester and effects on receptor degradation. Soc. Neurosci. Abstr. 13: 374.

Woodland, H., and L. Jones (1988) Growth factors in amphibian cell differentiation. Nature 332: 113-115. 